\title{
PENGARUH PEMBERIAN YOGHURT KACANG MERAH TERHADAP KADAR KOLESTEROL TOTAL PADA WANITA DISLIPIDEMIA
}

\author{
Karina Marcelia, Martha Irene Kartasurya*) \\ Program Studi Ilmu Gizi Fakultas Kedokteran Universitas Diponegoro \\ J1.Dr.Sutomo No.18, Semarang, Telp (024) 8453708, Email : gizifk@undip.ac.id
}

\begin{abstract}
Background : Dyslipidemia have been shown to be one of the factors associated to cardiovascular disease. Red beans contains proanthocyanidin, isoflavones and fibers that can lower total cholesterol level. Lactic acid bacteria from yogurt can lower total cholesterol level by incorporated to bacteria cell membrane, alteration of dehydrolate salt bile activity and increases isoflavones activities.

Aim: To analysis the effect of red bean yogurt consumption on total cholesterol level of dyslipidemic women.

Methods : This research was a true experiment pre-post test with control group design. Subjects were 26 premenopausal women with total cholesterol level $\geq 200 \mathrm{mg} / \mathrm{dL}$ (without medicine), who were divided into two groups, 13 in the control and 13 in the treatment groups. Red bean yogurt of $225 \mathrm{ml}$ per day were consumed for 15 days in treatment group. Both group received nutrition counseling at baseline. Total cholesterol level was measured with CHOD-PAP method. Food intake during intervention was measured using 3x24-hours food recall. Physical activity was measured by International Physical Activity Questionnaire (IPAQ). The statistical analyzes include Paired ttest, Wilcoxon, Independent t-test and Mann Whitney.

Result: Mean total cholesterol level in the treatment group decreased from $248.5 \pm 28.4 \mathrm{mg} / \mathrm{dL}$ to $205.2 \pm 31.1 \mathrm{mg} / \mathrm{dL}$ $(p=0.0001)$ while in the control group from $233.5 \pm 16.6 \mathrm{mg} / \mathrm{dL}$ to $213.0 \pm 20.6 \mathrm{mg} / \mathrm{dL}(p=0.009)$. The decrease of total cholesterol level in the treatment group $(43.3 \mathrm{mg} / \mathrm{dL}$ or $17.7 \%)$ was higher than control group (20.5 $\mathrm{mg} / \mathrm{dL}$ or $8.6 \%)$ with $p=0.001$. Total cholesterol level of $46.2 \%$ subjects in the treatment group and $23.1 \%$ subjects in the control group were normal after the intervention.
\end{abstract}

Conclusion : Consumption of $225 \mathrm{ml}$ red bean yogurt per day for 15 days decrease total cholesterol level in premenopause women with dyslipidemia who received nutrition counseling.

Keyword : Red bean yogurt; total cholesterol; dyslipidemia; pre-menopausal women

\begin{abstract}
ABSTRAK
Latar Belakang : Dislipidemia merupakan salah satu faktor risiko terjadinya penyakit jantung dan pembuluh darah. Kacang merah mengandung proantosianidin, isoflavon dan serat yang mampu menurunkan kadar kolesterol total. Bakteri asam laktat yang terkandung dalam yoghurt menurunkan kadar kolesterol total melalui inkorporasi dengan membran sel bakteri, perubahan aktivitas garam empedu terhidrolasi, dan peningkatan aktivitas isoflavon .

Tujuan: Menganalisis pengaruh pemberian yoghurt kacang merah terhadap kadar kolesterol total pada wanita dislipidemia

Metode : Jenis penelitian adalah true experiment dengan rancangan pre-post-test with control group. Subjek penelitian adalah 26 wanita pre-menopause dengan kadar kolesterol total $\geq 200 \mathrm{mg} / \mathrm{dL}$ (tanpa obat) yang dibagi menjadi dua kelompok, 13 pada kelompok kontrol dan 13 pada kelompok perlakuan. Kelompok perlakuan mendapatkan $225 \mathrm{ml}$ yoghurt kacang merah/hari selama 15 hari. Kedua kelompok mendapatkan konseling gizi di awal penelitian. Kadar kolesterol total diukur menggunakan metode CHOD-PAP. Asupan makanan selama intervensi diukur dengan metode food recall 3x24 jam dan dianalisis dengan nutrisurvey. Aktivitas fisik dianalisis dengan IPAQ. Analisis data menggunakan uji Paired t-test, Wilcoxon, Independent t-test dan Mann Whitney.

Hasil : Ada penurunan rerata kadar kolesterol total kelompok perlakuan dari 248,5 $+28,4$ mg/dL menjadi

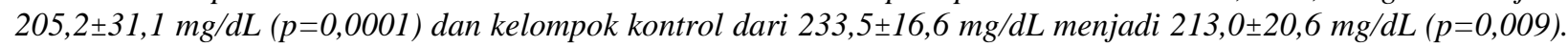
Penurunan kadar kolesterol total pada kelompok perlakuan lebih tinggi (43,3 mg/dL atau 17,7\%) daripada kelompok kontrol (20,5 mg/dL atau 8,6\%) dengan p=0,001. Kadar kolesterol total 46,2\% subjek kelompok perlakuan dan 23,1\% subjek kelompok kontrol menjadi normal setelah perlakuan.
\end{abstract}

Kesimpulan : Pemberian yoghurt kacang merah $225 \mathrm{ml} / \mathrm{hari}$ selama 15 hari menurunkan kadar kolesterol total pada wanita pre-menopause dengan dislipidemia yang diberi konseling gizi.

Kata kunci : Yoghurt kacang merah; kolesterol total; dislipidemia; wanita pre-menopause

\section{PENDAHULUAN}

Penyakit kardiovaskular merupakan salah satu dari non-communicable diseasse (NCDs) yang menjadi penyebab utama kematian di dunia. ${ }^{1}$ Pada tahun 2008, diperkirakan 17,5 juta penduduk (30\% kematian secara global) meninggal dikarenakan penyakit kardiovaskular. Dari angka kematian tersebut, diperkirakan 7,3 juta penduduk meninggal dikarenakan penyakit jantung dan 6,2 juta penduduk meninggal dikarenakan stroke. ${ }^{2}$ Berdasarkan sebuah penelitian di Indonesia pada tahun 2009 didapatkan hasil prevalensi penyakit 
jantung tertinggi berada di Provinsi Sulawesi Tengah $(16,9 \%)$, DI Aceh $(16,6 \%)$, Gorontalo $(16,0 \%)$, Sumatera Barat $(15,4 \%)$, dan Nusa Tenggara Timur (13,0\%). Sementara di Provinsi Jawa Tengah, prevalensi penyakit jantung sebesar $10,7 \% .^{3}$

Beberapa faktor risiko penyakit jantung dan pembuluh darah telah diketahui diantaranya adalah merokok, gaya hidup sedentary, obesitas, aktivitas fisik, peningkatan tekanan darah, diabetes, dan ketidaknormalan fraksi lipid (dislipidemia). ${ }^{4,5}$ Suatu penelitian menyebutkan bahwa dislipidemia merupakan faktor risiko terpenting dalam proses terjdinya aterosklerosis dan berhubungan kuat dengan terjadinya penyakit jantung dan pembuluh darah. ${ }^{6}$

Dislipidemia merupakan kelainan metabolisme lipid yang ditandai dengan peningkatan kadar kolesterol total, kolesterol LDL (Low-Density Lipoprotein), trigliserida, serta penurunan kadar kolesterol HDL (High-Density Lipoprotein). ${ }^{7}$ Hasil Riskesdas tahun 2013 menyatakan bahwa proporsi penduduk $\geq 15$ tahun dengan kadar kolesterol total di atas nilai normal (kolesterol total $\geq 200 \mathrm{mg} / \mathrm{dL}$ ) menurut National Cholesterol Education Program Adult Panel III (NCEP-ATP III) adalah sebesar 35,9\%. ${ }^{4}$

Pengaturan pola makan dan modifikasi diet merupakan salah satu upaya dalam menurunkan kadar kolesterol total. Modifikasi diet yang diterapkan adalah dengan mengurangi asupan lemak total dan lemak jenuh serta meningkatkan asupan lemak tidak jenuh tunggal dan ganda. ${ }^{7,8}$ Selain itu, dianjurkan juga mengkonsumsi bahan makanan dengan efek hipokolesterol sebagai alternatif pangan yang dapat memperbaiki serum kolesterol darah salah satunya dengan kacang merah. ${ }^{9,10,11}$

Kacang merah merupakan salah satu bahan pangan yang memiliki efek hipokolesterol. Hal ini dikarenakan dalam kacang merah mengandung serat (larut dan tidak larut) serta flavonoid (proantosianidin dan isoflavon). ${ }^{10,12,13}$ Serat larut air memberikan efek yang signifikan dalam menurunkan kadar kolesterol melalui berbagai mekanisme salah satunya dengan mengikat asam empedu dan meningkatkan ekskresinya dalam feses. ${ }^{14}$ Flavonoid yang terkandung dalam kacang merah salah satunya adalah proantosianidin. Proantosianidin berperan dalam menurunkan kadar kolesterol dengan menghambat pembentukan malonaldehid dan aktivitas lipase. ${ }^{10,15}$ Flavonoid lainnya yang terkandung dalam kacang merah adalah isoflavon. Kandungan isoflavon dalam kacang merah yang berperan dalam penurunan kadar kolesterol adalah daidzein $(527 \mu \mathrm{g} / \mathrm{g})$ dan genistein $(389 \mu \mathrm{g} / \mathrm{g})$ dengan cara menghambat sekresi hepatosit apo- $\beta .^{16}$

Pengolahan kacang merah dengan cara difermentasi menggunakan bakteri asam laktat dapat meningkatkan nilai gizi pada produk yoghurt kacang merah. Aktivitas antioksidan pada kacang merah akan menjadi lebih baik dikarenakan adanya enzim yg dihasilkan oleh bakteri asam laktat dapat menghidrolisis senyawa isoflavon menjadi senyawa isoflavon bebas dalam bentuk aktif yang disebut dengan aglikon. Selain itu, bakteri asam laktat juga berperan langsung dalam menurunkan kolesterol melalui mekanisme asimilasi kolesterol, perubahan aktivitas garam empedu terhidrolasi dan efek antioksidan. ${ }^{17}$ Berdasarkan penelitian terdahulu terhadap tikus dislipidemia yang diberi jus kacang merah (4 ml), yoghurt susu (4 ml), dan yoghurt kacang merah $(4 \mathrm{ml})$ selama 28 hari diketahui bahwa perbedaan kadar kolesterol total masing-masing adalah $0,5 \pm 0,09 \mathrm{mg} / \mathrm{dL}, 0,5 \pm 0,12$ $\mathrm{mg} / \mathrm{dL}$, dan $-0,2 \pm 0,09 \mathrm{mg} / \mathrm{dL}$. Penurunan kadar kolesterol total secara signifikan terjadi pada kelompok perlakuan pemberian yoghurt kacang merah yang difermentasi menggunakan bakteri Lactobacillus bulgaricus dan Streptococcus thermophilus. ${ }^{9}$ Berdasarkan uraian di atas, maka peneliti ingin melakukan penelitian tentang pengaruh pemberian yoghurt kacang merah terhadap kadar kolesterol total pada wanita dislipidemia. Penelitian ini bertujuan untuk mengetahui pengaruh pemberian yoghurt kacang merah terhadap kadar kolesterol total pada wanita dislipidemia.

\section{METODE}

Penelitian ini merupakan penelitian true experiment dengan rancangan pre-test-post-test with control group. Variabel bebas dalam penelitian ini adalah pemberian yoghurt kacang merah dengan dosis $225 \mathrm{ml}$, sementara variabel terikat adalah kadar kolesterol total penderita dislipidemia. Yoghurt kacang merah dibuat dengan metode Illinois dimodifikasi. Kacang merah direndam semalam, kemudian ditiriskan. Kacang merah tersebut lalu direbus pada air mendidih selama 20 menit. Kacang merah yang telah direbus kemudian diblender dengan perbandingan air rebusan kacang merah dan kacang merah 4:1. Kacang merah yang telah diblender lalu direbus sampai suhu $70^{\circ} \mathrm{C}$ kemudian ditambah dengan susu skim sebanyak 5\%. Setelah itu, perebusan dilanjutkan sampai suhunya mencapai $80^{\circ} \mathrm{C}$ dan kemudian didinginkan hingga $40^{\circ} \mathrm{C}$ untuk ditambah dengan starter (Lactobacillus bulgaricus 
dan Steptococcus thermophilus) sebanyak 5\%, kemudian diinkubasi selama 4 jam dalam inkubator dengan suhu $45^{\circ} \mathrm{C}$. Setelah itu, dilakukan pemorsian yoghurt kacang merah $(225 \mathrm{ml} /$ gelas $)$ dan penambahan gula buatan sebanyak 2,5 g/gelas, kemudian dipindahkan ke pendingin dengan suhu $4^{\circ} \mathrm{C}$. Pelaksanaan penelitian telah mendapat persetujuan dari Komisi Etik Fakultas Kedokteran Universitas Diponegoro melalui terbitnya Ethical Clearance. Pengambilan data sampel dilakukan setelah mendapat persetujuan dari subjek dengan mengisi informed consent.

Subjek penelitian merupakan karyawati kantor Badan Perencanaan Pembangunan Daerah Provinsi Jawa Tengah dan SMP Dominico Savio Yayasan Pangudi Luhur Semarang. Kriteria inklusi penelitian ini adalah memiliki kadar kolesterol total $\geq 200 \mathrm{mg} / \mathrm{dL}$, belum mengalami menopause, tidak sedang mengonsumsi obat antidislipidemia selama penelitian, tidak dalam keadaan sakit atau dalam perawatan dokter berkaitan dengan penyakit jantung koroner, diabetes melitus, hipertensi, gagal ginjal, dan penyakit kronik lainnya.

Perhitungan subjek penelitian menggunakan rumus uji hipotesis terhadap rerata dua populasi independen dan dibutuhkan sebanyak 26 subjek. Penentuan subjek penelitian menggunakan metode purposive sampling. Subjek dibagi menjadi 2 kelompok secara random (acak), yang terdiri atas kelompok kontrol dan kelompok perlakuan, masing-masing kelompok terdiri dari 13 subjek. Kelompok perlakuan mendapatkan yoghurt kacang merah sebanyak $225 \mathrm{ml} /$ hari selama 15 hari. Kedua kelompok mendapatkan konseling gizi mengenai diet rendah kolesterol dan lemak terbatas di awal penelitian.

Asupan makan sehari-hari, pada kelompok kontrol dan kelompok perlakuan tidak dikontrol. Pencatatan asupan makanan dilakukan selama intervensi dengan menggunakan metode food recall $3 \times 24$ jam, kemudian dianalisis menggunakan program nutrisurvey. Kecukupan asupan makanan (\%) dihitung berdasarkan kebutuhan subjek menurut golongan umur dan jenis kelamin pada AKG 2013. Aktivitas fisik dianalisis menggunakan kuesioner aktivitas fisik International Physical Activity Questionnaire (IPAQ). Aktivitas fisik yang dilaporkan oleh subjek mencakup kegiatan yang hanya dilakukan selama tujuh hari terakhir selama penelitian. Skor aktivitas fisik dihitung berdasarkan protokol skoring IPAQ dan dinyatakan dalam satuan METmenit/minggu, penggolongannya yaitu rendah (<600 MET-menit/minggu), sedang (600-2999 MET-menit/minggu), dan tinggi ( $\geq 3000$ METmenit/minggu). Indeks masa tubuh ditentukan berdasarkan klasifikasi indeks massa tubuh pada orang dewasa Asia yaitu kategori normal (18,5$\left.22,9 \mathrm{~kg} / \mathrm{m}^{2}\right)$, overweight $\left(23-24,9 \mathrm{~kg} / \mathrm{m}^{2}\right)$ dan obesitas $\left(>25 \mathrm{~kg} / \mathrm{m}^{2}\right)$. Kepatuhan subjek mengonsumsi yoghurt kacang merah dicatat dengan menggunakan formulir tingkat asupan yoghurt kacang merah. Pemeriksaan kadar kolesterol total dilakukan dua kali, yaitu sebelum intervensi dan setelah intervensi (hari ke-16). Pengukuran kadar kolesterol total dilakukan oleh laboratorium "Permata" menggunakan metode Cholesterol Oxidase Para Aminophenazone (CHOD-PAP). Sampel darah diambil oleh petugas laboratorium setelah subjek berpuasa selama \pm 10 jam.

Untuk menguji normalitas data menggunakan uji Shapiro-Wilk. Analisis deskriptif digunakan untuk melihat gambaran karakteristik subjek. Perbedaan kadar kolesterol total sebelum dan sesudah intervensi menggunakan paired t-test untuk data kelompok perlakuan dan uji Wilcoxon untuk data kelompok kontrol. Perbedaan pengaruh konsumsi yoghurt kacang merah dianalisis dengan menggunakan uji independent $t$-test.

\section{HASIL PENELITIAN \\ Subjek Penelitian}

Subjek dalam penelitian ini adalah karyawati dislipidemia yang berada di kantor Badan Perencanaan Pembangunan Daerah Provinsi Jawa Tengah dan SMP Dominico Savio Yayasan Pangudi Luhur Semarang. Bagan subjek penelitian dapat dilihat pada Gambar 1.

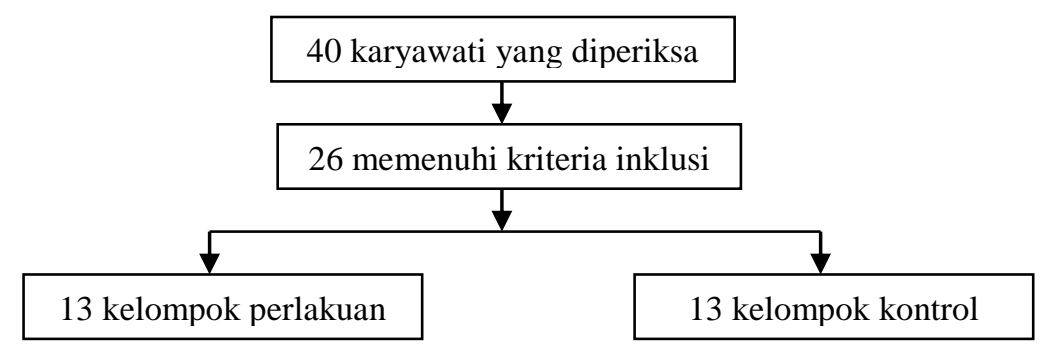

Gambar 1. Bagan Subjek Penelitian 
Pembagian subjek menjadi 2 kelompok dilakuan secara acak. Tidak terdapat sampel yang droup out sampai akhir penelitian.

\section{Karakteristik Subjek}

Sampel dalam penelitian ini berjumlah 26 orang yang terdiri dari kelompok perlakuan dan kelompok kontrol masing-masing kelompok berjumlah 13 orang. Keadaan subjek pada awal penelitian ditampilkan untuk mengetahui homogenitas variabel pada kedua kelompok dapat dilihat pada Tabel 1 .

Tabel 1. Keadaan Subjek Pada Awal Penelitian

\begin{tabular}{lccc}
\hline \multirow{2}{*}{ Variabel } & Perlakuan $(\mathbf{n}=\mathbf{1 3})$ & Kontrol $(\mathbf{n}=\mathbf{1 3})$ & \multirow{2}{*}{$\mathbf{p}$} \\
\cline { 2 - 3 } & Rerata \pm SD & Rerata \pm SD & \\
\hline Umur (tahun) & $43,8 \pm 5,9$ & $40,5 \pm 7,5$ & $0,216^{\mathrm{a}}$ \\
Indeks Masa Tubuh $\left(\mathbf{k g} / \mathbf{m}^{2}\right)$ & $27,8 \pm 4,9$ & $25,6 \pm 3,9$ & $0,211^{\mathrm{a}}$ \\
Aktivitas fisik (MET-menit/minggu) & $1010,2 \pm 1008,2$ & $1278,5 \pm 2633,5$ & $0,666^{\mathrm{a}}$ \\
Kolesterol total awal $(\mathbf{m g} / \mathbf{d L})$ & $248,5 \pm 28,4$ & $233,5 \pm 16,6$ & $0,228^{\mathrm{b}}$ \\
\hline
\end{tabular}

${ }^{\text {andependent t-test }}$

${ }^{\mathrm{b} M a n n}$ Whitney

Tabel 1 menunjukkan tidak terdapat kelompok sebelum dilakukan intervensi. perbedaan umur, Indeks Masa Tubuh (IMT), Karakteristik subjek yang meliputi IMT dan aktivitas fisik, dan kolesterol total awal pada kedua aktivitas fisik dirinci pada Tabel 2.

Tabel 2. Karakteristik Subjek

\begin{tabular}{lcccc}
\hline \multirow{2}{*}{ Variabel } & \multicolumn{2}{c}{ Perlakuan $(\mathbf{n = 1 3})$} & \multicolumn{2}{c}{ Kontrol (n=13) } \\
\cline { 2 - 5 } & $\mathbf{n}$ & $\mathbf{0}$ & $\mathbf{n}$ & $\mathbf{\%}$ \\
\hline Indeks Masa Tubuh & 3 & $23,1 \%$ & 5 & $38,5 \%$ \\
$\quad$ Normal & 0 & $0 \%$ & 2 & $15,4 \%$ \\
$\quad$ Overweight & 10 & $76,9 \%$ & 6 & $46,2 \%$ \\
$\quad$ Obesitas & & & & \\
\hline Aktivitas fisik & 8 & $61,5 \%$ & 8 & $61,5 \%$ \\
$\quad$ Rendah & 5 & $38,5 \%$ & 4 & $30,8 \%$ \\
Sedang & 0 & $0 \%$ & 1 & $7,7 \%$ \\
$\quad$ Tinggi & & &
\end{tabular}

Tabel 2 menunjukkan sebagian besar subjek pada kelompok perlakuan berada pada kategori IMT obesitas $(76,9 \%)$, sedangkan pada kelompok kontrol sebagian besar subjek berada pada kategori IMT overweight dan obesitas $(61,6 \%)$. Selain itu, diketahui juga bahwa aktivitas fisik kedua kelompok sebagian besar dalam kategori rendah $(61,5 \%)$.

\section{Asupan Zat Gizi Selama Intervensi}

Persen kecukupan kebutuhan zat gizi, asupan kolesterol, asupan Polyunsaturated Fatty Acids (PUFA), Monounsaturated Fatty Acids (MUFA) dan asupan Saturated Fatty Acids (SFA) selama intervensi pada kedua kelompok dapat dilihat pada Tabel 3.

Tabel 3. Persen Kecukupan Kebutuhan Zat Gizi, Asupan Kolesterol, Asupan PUFA, Asupan MUFA dan Asupan SFA Selama Intervensi

\begin{tabular}{|c|c|c|c|}
\hline \multirow{2}{*}{ Variabel } & Perlakuan $(n=13)$ & Kontrol $(\mathrm{n}=13)$ & \multirow[t]{2}{*}{$\mathbf{p}$} \\
\hline & Rerata \pm SD & Rerata \pm SD & \\
\hline Kecukupan energi* $\left.^{*} \%\right)$ & $65,6 \pm 21,7$ & $70,8 \pm 18,9$ & $0,360^{\mathrm{a}}$ \\
\hline Kecukupan karbohidrat* $(\%)$ & $57,9 \pm 20,6$ & $62,3 \pm 14,6$ & $0,209^{\mathrm{b}}$ \\
\hline Kecukupan lemak*(\%) & $86,2 \pm 36,6$ & $93,8 \pm 34,1$ & $0,587^{\mathrm{a}}$ \\
\hline Kecukupan protein*(\%) & $85,5 \pm 23,9$ & $94,2 \pm 27,8$ & $0,400^{\mathrm{a}}$ \\
\hline Kecukupan serat* $(\%)$ & $29,5 \pm 12,8$ & $35,6 \pm 13,0$ & $0,136^{\mathrm{a}}$ \\
\hline Asupan kolesterol (mg) & $206,4 \pm 72,4$ & $203,3 \pm 127,5$ & $0,462^{\mathrm{a}}$ \\
\hline Asupan Polyunsaturated Fatty Acids (\%) & $6,5 \pm 2,5$ & $6,8 \pm 2,4$ & $0,758^{\mathrm{a}}$ \\
\hline Asupan Monounsaturated Fatty Acids (\%) & $7,8 \pm 2,0$ & $8,2 \pm 2,2$ & $0,677^{\mathrm{a}}$ \\
\hline
\end{tabular}




\begin{tabular}{|c|c|c|}
\hline Asupan Saturated Fatty Acids (\%) & $14,1 \pm 2,6$ & $0,316^{\mathrm{a}}$ \\
\hline
\end{tabular}

Tabel 3 menunjukkan persen kecukupan kebutuhan zat gizi subjek menurut golongan umur dan jenis kelamin pada AKG 2013. Persen kecukupan energi pada kelompok perlakuan serta karbohidrat dan serat pada kedua kelompok tergolong defisit $(<70 \%)$. Persen kecukupan lemak dan protein kedua kelompok tergolong sedang (8099\%). Asupan kolesterol dan SFA kedua kelompok tergolong tinggi, sedangkan asupan PUFA $(<10 \%)$ dan MUFA $(<20 \%)$ kedua kelompok tergolong rendah. Berdasarkan uji beda, tidak terdapat perbedaan bermakna persen kecukupan energi, karbohidrat, lemak, protein, serat, asupan kolesterol, PUFA, MUFA, dan SFA pada kedua kelompok. Grafik rerata asupan makanan selama intervensi dapat dilihat pada Gambar 2, 3, 4, dan 5.

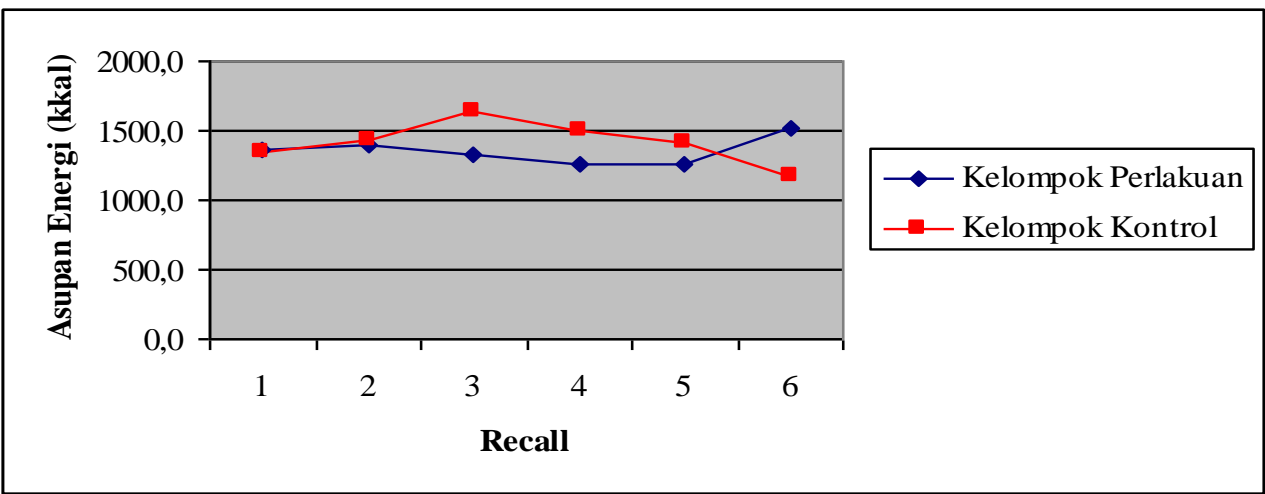

Gambar 2. Grafik Rerata Asupan Energi Selama Intervensi pada Kedua Kelompok

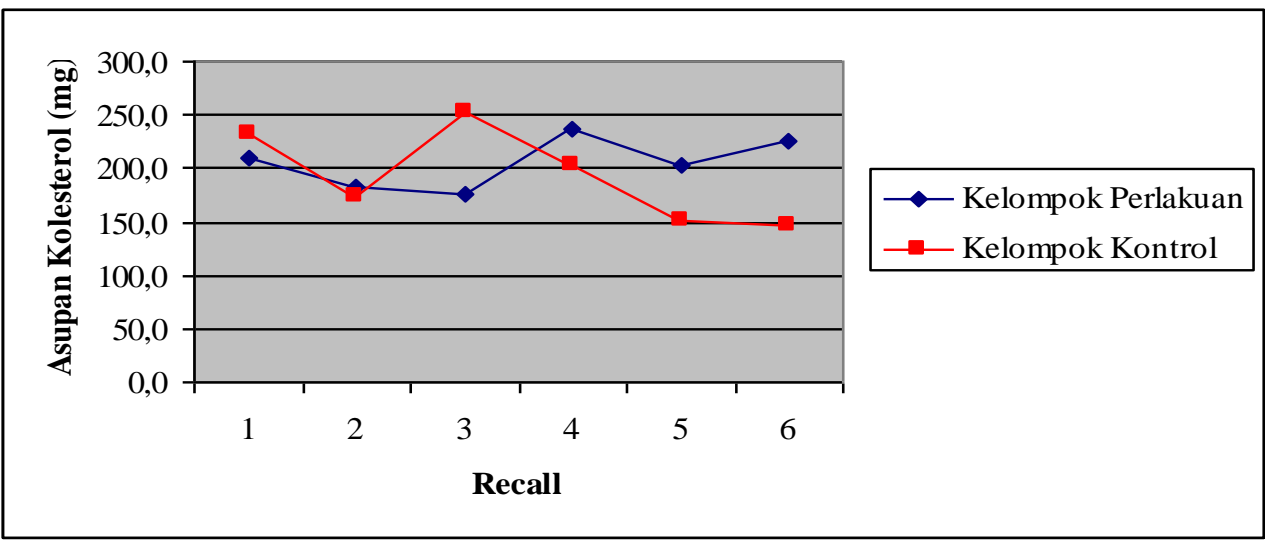

Gambar 3. Grafik Rerata Asupan Kolesterol Selama Intervensi pada Kedua Kelompok

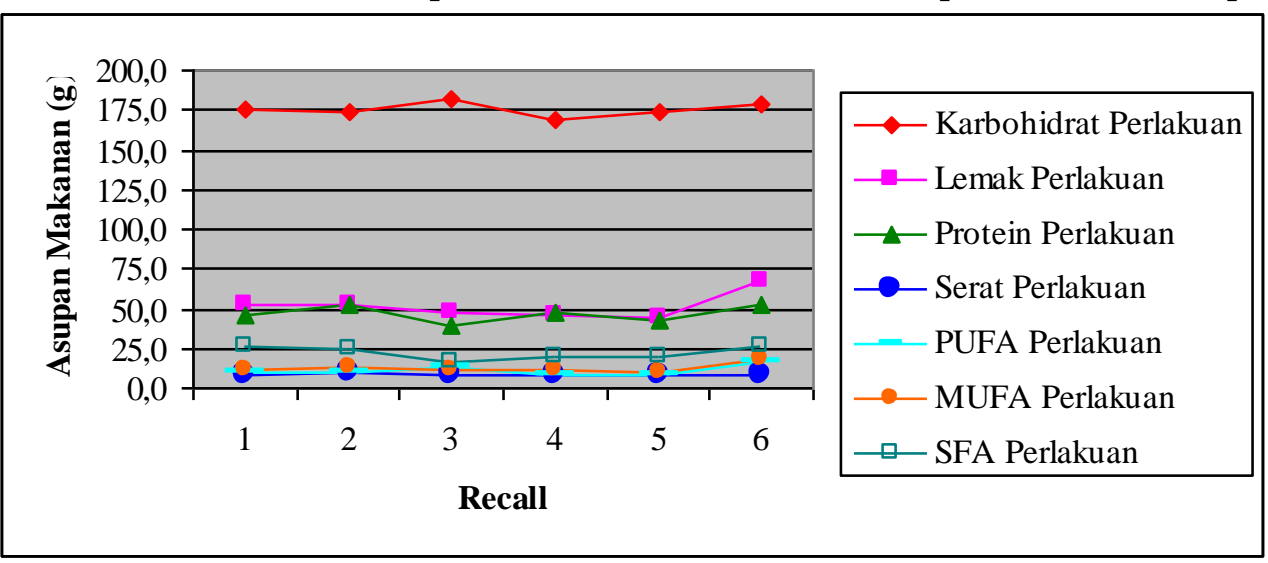

Gambar 4. Grafik Rerata Asupan Karbohidrat, Lemak, Protein, Serat, PUFA, MUFA, dan SFA Selama Intervensi pada Kelompok Perlakuan 


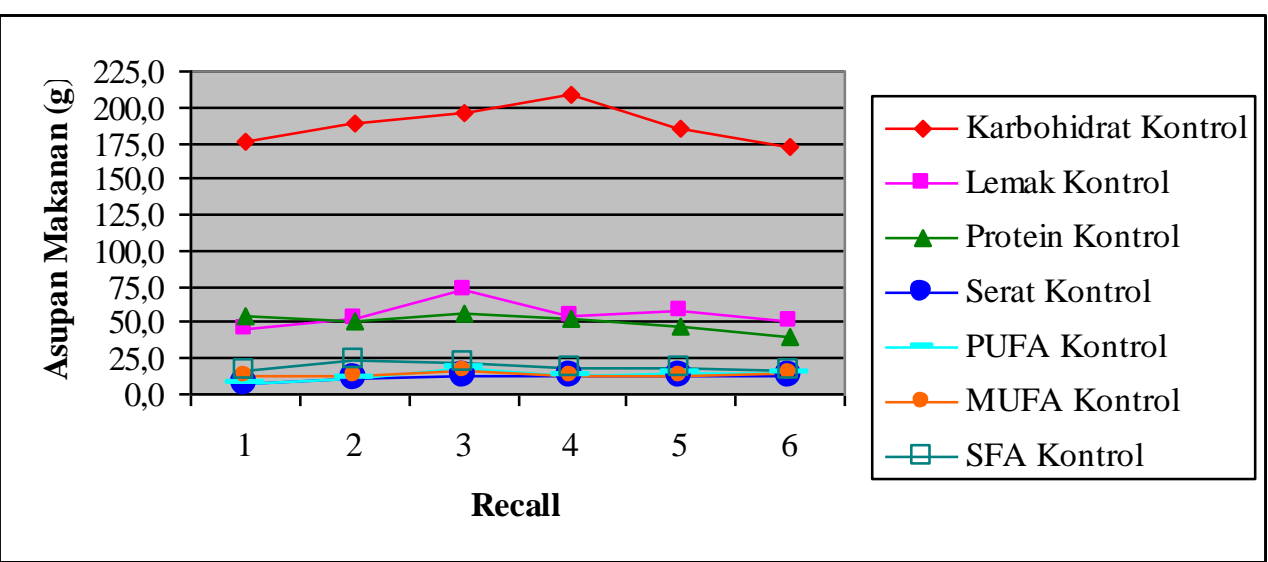

Gambar 5. Grafik Rerata Asupan Karbohidrat, Lemak, Protein, Serat, PUFA, MUFA, dan SFA Selama Intervensi pada Kelompok Kontrol

Grafik 2, 3, 4, dan 5 menunjukkan perubahan asupan makanan selama intervensi pada kedua kelompok. Pada kelompok perlakuan terjadi peningkatan asupan PUFA dan MUFA, sedangkan pada kelompok kontrol terjadi penurunan asupan energi, kolesterol, dan SFA serta peningkatan asupan serat, PUFA, dan MUFA.
Tingkat Asupan Yoghurt Kacang Merah

Selama penelitian, kelompok perlakuan mendapat intervensi berupa yoghurt kacang merah sebanyak $225 \mathrm{ml} /$ hari. Tingkat asupan yoghurt kacang merah selama penelitian adalah $100 \%$.

Pengaruh Yoghurt Kacang Merah Terhadap Kadar Kolesterol Total

Kadar kolesterol total sebelum dan setelah pemberian yoghurt kacang merah dapat dilihat pada Tabel 4.

Tabel 4. Perbedaan Kadar Kolesterol Total Sebelum dan Setelah Intervensi

\begin{tabular}{lccc}
\hline \multirow{2}{*}{ Kolesterol Total $(\mathbf{m g} / \mathbf{d L})$} & Perlakuan $(\mathbf{n}=\mathbf{1 3})$ & Kontrol $(\mathbf{n}=\mathbf{1 3})$ & $\mathbf{p}$ \\
\cline { 2 - 3 } & Rerata \pm SD & Rerata \pm SD & \\
\hline Sebelum & $248,5 \pm 28,4$ & $233,5 \pm 16,6$ & \\
Setelah & $205,2 \pm 31,1$ & $213,0 \pm 20,6$ & $0,456^{\mathrm{a}}$ \\
Penurunan (setelah-sebelum) & $43,3 \pm 11,2$ & $20,5 \pm 18,7$ & $0,001^{\mathrm{a}}$ \\
Persentase penurunan & $17,7 \%$ & $8,6 \%$ & \\
$\mathbf{p}$ & $0,0001^{\mathrm{c}}$ & $0,009^{\mathrm{d}}$ & \\
\hline${ }^{\mathrm{a}}$ Independent t-test & & & \\
${ }^{\mathrm{c}}$ Paired t-test & & & \\
${ }^{\mathrm{d}}$ Wilcoxon & &
\end{tabular}

Hasil uji beda menunjukkan adanya perbedaan bermakna kolesterol total sebelum dan sesudah perlakuan pada kedua kelompok. Terdapat perbedaan bermakna penurunan kadar kolesterol total antara kedua kelompok. Pada kelompok perlakuan, penurunan kadar kolesterol total lebih tinggi daripada kelompok kontrol.

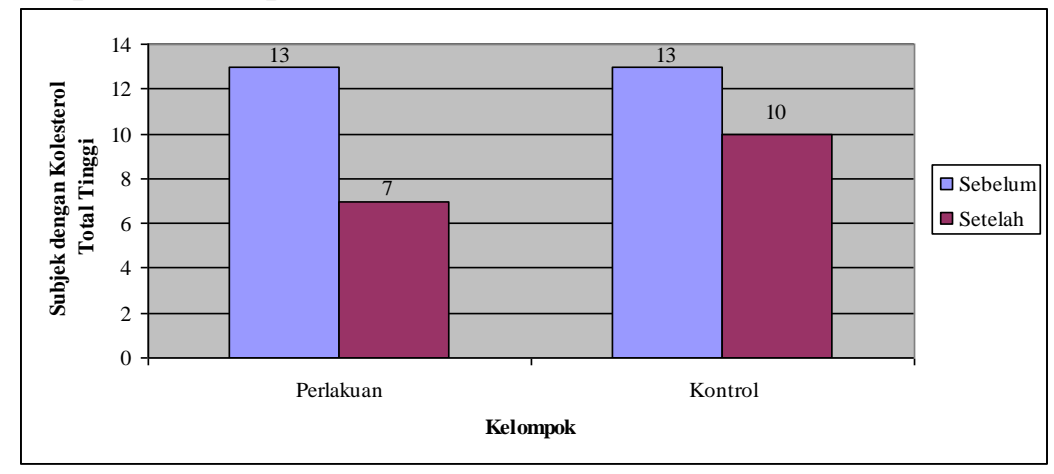

Gambar 6. Grafik Penderita Dislipidemia (Kadar Kolesterol Total Tinggi) pada Kedua Kelompok Sebelum dan Setelah Pemberian Yoghurt Kacang Merah 
Gambar 6 menunjukkan bahwa kadar kolesterol total awal kedua kelompok tergolong tinggi ( $\geq 200 \mathrm{mg} / \mathrm{dL})$. Setelah intervensi selama 15 hari, kadar kolesterol total 6 subjek kelompok perlakuan (46,2\%) dan 3 subjek kelompok kontrol $(23,1 \%)$ menjadi normal.

\section{PEMBAHASAN}

Tidak terdapat perbedaan umur, IMT, aktivitas fisik, dan kolesterol total sebelum intervensi antara kelompok kontrol dan perlakuan. Hal ini dapat disimpulkan bahwa, subjek pada penelitian ini tergolong homogen. Karakteristik subjek dalam penelitian ini adalah wanita dislipidemia yang belum mengalami menopause. Risiko dislipidemia pada wanita meningkat seiring dengan pertambahan usia dan indeks masa tubuh (IMT). ${ }^{18}$

Indeks masa tubuh sebagian besar subjek adalah obesitas (IMT $>25 \mathrm{~kg} / \mathrm{m}^{2}$ ), yakni sebesar $76,9 \%$ pada kelompok perlakuan dan $46,2 \%$ pada kelompok kontrol. Pada kondisi indeks masa tubuh yang berlebihan, terjadi kelebihan lemak pada jaringan adiposa. ${ }^{19}$ Keadaan ini, dapat meningkatkan faktor risiko dislipidemia dikarenakan berat badan berlebih cenderung mempunyai kadar kolesterol yang lebih tinggi dan jumlah HDL yang rendah. ${ }^{20}$

Aktivitas fisik sebagian besar subjek termasuk dalam kategori aktivitas fisik rendah (<600 MET-menit/minggu), yaitu sebesar $61,5 \%$ pada masing-masing kelompok. Aktivitas fisik yang rendah merupakan faktor risiko independen terjadinya penyakit jantung dan pembuluh darah. ${ }^{19}$ Sebuah penelitian melaporkan bahwa risiko penyakit jantung dan pembuluh darah menjadi dua kali lipat pada wanita yang aktivitas fisiknya kurang. ${ }^{21}$ Sementara itu, aktivitas fisik yang teratur (olahraga teratur) dapat meningkatkan kadar kolesterol HDL. ${ }^{19}$ Selain itu, olahraga teratur juga dapat meningkatkan aktivitas berbagai enzim yang bertanggung jawab terhadap oksidasi lemak sehingga lebih banyak lemak yang digunakan sebagai sumber energi. ${ }^{20}$

Tidak terdapat perbedaan kadar kolesterol total sebelum intervensi pada kedua kelompok. Pemberian yoghurt kacang merah selama 15 hari dapat menurunkan kadar kolesterol total. Terbukti pada kelompok kontrol terjadi penurunan kadar kolesterol total tetapi tidak sebesar kelompok perlakuan. Hasil uji statistik menunjukkan perbedaan bermakna penurunan kadar kolesterol total antara kedua kelompok. Pada kelompok kontrol, terjadi penurunan kolesterol total sebesar
$8,6 \%$, sedangkan pada kelompok perlakuan terjadi penurunan kolesterol total sebesar $17,7 \%$.

Penurunan kadar kolesterol total pada kelompok kontrol dapat disebabkan berbagai faktor seperti konseling gizi, asupan makanan, dan aktivitas fisik selama intervensi. Target utama dari proses konseling gizi adalah adanya perubahan gaya hidup, termasuk didalamnya adalah perubahan kebiasaan dan pola makan. ${ }^{22}$ Dalam penelitian ini, konseling gizi mengenai diet rendah kolesterol dan lemak terbatas hanya diberikan di awal penelitian pada kedua kelompok. Penurunan kadar kolesterol total pada kelompok kontrol dimungkinkan karena subjek pada kelompok kontrol menerapkan materi konseling dalam kehidupan sehari-hari.

Walaupun tidak terdapat perbedaan antara kedua kelompok, asupan selama intervensi juga dapat menjadi salah satu faktor turunnya kadar kolesterol total kelompok kontrol, khususnya asupan serat, kolesterol, PUFA, MUFA, dan SFA. Berdasarkan hasil analisis food recall $3 \times 24$ jam selama penelitian, terjadi peningkatan asupan serat, PUFA, dan MUFA serta penurunan asupan kolesterol dan SFA pada kelompok kontrol.

National Heart, Lung, and Blood Institute (NHLBI) menganjurkan asupan serat 25-30 g/hari, kolesterol $<200 \mathrm{mg} / \mathrm{hari}$, PUFA sampai dengan $10 \%$ total kalori, MUFA sampai dengan 20\% total kalori, dan SFA $<7 \%$ total kalori. ${ }^{19}$ Asupan kolesterol dan SFA pada kedua kelompok tergolong tinggi jika dibandingkan dengan anjuran NHLBI, sedangkan asupan serat, PUFA, dan MUFA kedua kelompok tergolong rendah. Tingginya asupan kolesterol dalam diet dapat meningkatkan kadar kolesterol total dan kolesterol LDL, tetapi pengaruhnya tidak terlalu besar dibandingkan asupan SFA. Peningkatan asupan kolesterol sebanyak $100 \mathrm{mg}$ dapat meningkatkan kadar kolesterol total sebesar $5 \mathrm{mg} / \mathrm{dL}$, sedangkan peningkatan asupan SFA $(>7 \%)$ dapat meningkatkan kadar kolesterol total sebesar 15$25 \% .{ }^{29,30}$ Berbanding terbalik, diet tinggi PUFA dan MUFA dapat menurunkan kolesterol melalui mekanisme penambahan jumlah (up-regulation) reseptor LDL sehingga terjadi peningkatan laju katabolik LDL. ${ }^{23}$

Penurunan kadar kolesterol total pada kelompok perlakuan lebih besar dibandingkan dengan kelompok kontrol. Pada kelompok perlakuan, terjadi penurunan kolesterol total sebesar 43,3 mg/dL (17,7\%). Persen penurunan kolesterol ini mendekati rekomendasi dari Departement of Health in England and Wales, yakni persen penurunan kolesterol total yang 
dianjurkan sebesar 25\% pada pasien yang menerima terapi statin dan konseling gizi. ${ }^{28}$ Penurunan kolesterol total pada kelompok perlakuan ini sejalan dengan penelitian sebelumnya yaitu pemberian yoghurt kacang merah $4 \mathrm{ml} /$ hari selama 28 hari terhadap tikus dislipidemia signifikan menurunkan kadar kolesterol total. ${ }^{9}$ Penurunan kolesterol total pada kelompok perlakuan disebabkan karena kandungan zat gizi dalam kacang merah dan bakteri asam laktat dalam yoghurt.

Kacang merah mengandung proantosianidin, isoflavon, dan serat yang memiliki efek hipokolesterol. Proantosianidin dalam kacang merah berperan dalam menurunkan kadar kolesterol dengan menghambat pembentukan malonaldehid (MDA) dan aktivitas lipase pankreas. MDA merupakan salah satu produk akhir dari peroksidasi lipid yang terbentuk setelah senyawa radikal menyerang membran lipid yang mengandung asam lemak tak jenuh ganda (PUFA). Lipase pankreas merupakan enzim yang berperan dalam absorpsi trigliserida dalam usus. Penghambatan aktivitas lipase pankreas ini dapat menurunkan penyerapan monogliserida dan asam lemak. $^{24}$

Kacang merah mengandung $527 \mu \mathrm{g} / \mathrm{g}$ daidzein dan $389 \mu \mathrm{g} / \mathrm{g}$ genistein. ${ }^{12}$ Isoflavon yang terdapat pada kacang merah ini dapat menghambat proses biosintesis kolesterol melalui aktivasi enzim Adenosine Monophosphate Activates Protein Kinase (AMPK). ${ }^{25}$ Enzim ini menyebabkan terhambatnya reduksi HMG-KoA menjadi mevalonat sehingga dapat mengurangi biosintesis kolesterol di dalam tubuh. Selain itu, isoflavon dalam kacang merah juga dapat menurunkan sekresi apolipoprotein- $\beta$ melalui berbagai mekanisme, termasuk dengan menghambat sintesis dan esterifikasi kolesterol, menghambat aktivitas microsomal transfer protein (MTP), dan meningkatkan ekspresi reseptor LDL. ${ }^{16}$

Selain mengandung flavonoid, kacang merah juga mengandung 4-7,7 g/100 g serat, terdiri dari $2 \mathrm{~g} / 100 \mathrm{~g}$ serat larut air dan 5,7 g/100g serat tidak larut air. Serat yang membantu menurunkan kolesterol adalah serat larut air, yakni dengan cara mempengaruhi absorpsi dan metabolisme asam empedu. Serat akan mengikat asam empedu dan meningkatkan ekskresinya dalam feses sehingga dibutuhkan peningkatan fluks kolesterol ke dalam jalur sintesa asam empedu dan menyebabkan sedikitnya kolesterol yang tersedia untuk jalur sintesa lipoprotein. ${ }^{14}$

Bakteri asam laktat (BAL) yang terkandung dalam yoghurt kacang merah juga berperan dalam menurunkan kolesterol melalui mekanisme asimilasi kolesterol dan perubahan aktivitas garam empedu terhidrolasi. Asimilasi kolesterol terjadi melalui mekanisme pengambilan kolesterol oleh BAL. Kolesterol tersebut lalu berinkoporasi dengan membran sel bakteri sehingga menyebabkan berkurangnya jumlah kolesterol bebas yang ada dalam tubuh. Sementara perubahan aktivitas garam empedu terhidrolasi mengakibatkan asam empedu menjadi sulit diabsorpsi kembali sehingga akan lebih banyak asam empedu yang akan diekskresikan melalui feses. ${ }^{17}$

Selain berperan langsung dalam menurunkan kadar kolesterol, bakteri asam laktat yang digunakan dalam proses fermentasi juga berperan secara tidak langsung dalam metabolisme isoflavon. Selama pertumbuhannya, bakteri asam laktat akan menghasilkan enzim, salah satunya yakni enzim $\beta$-glukosidase. ${ }^{26}$ Enzim ini berperan dalam menghidrolisis isoflavon dalam kacang merah sehingga menghasilkan isoflavon yang tidak berkonjugasi dengan glukosa yang disebut aglikon. Aglikon merupakan bentuk aktif yang diperlukan tubuh karena mudah diserap oleh usus dan diketahui bahwa senyawa ini dapat menekan kadar kolesterol. Untuk mendapatkan efek hipokolesterol, para ahli merekomendasikan asupan isoflavon orang dewasa dalam bentuk aglikon sebanyak 30-60 mg/hari. ${ }^{27}$

\section{SIMPULAN}

Pemberian yoghurt kacang merah 225 $\mathrm{ml} /$ hari selama 15 hari menurunkan kadar kolesterol total pada wanita pre-menopause dengan dislipidemia yang diberi konseling gizi.

\section{DAFTAR PUSTAKA}

1. Fakhrzadeh H, Ozra Tabatabaei-Malazy. Dyslipidemia and Cardiovascular Disease. In: Kelishadi R, editors. Dyslipidemia - From Prevention to Treatment. Croatia: InTech; 2012.p.303.

2. World Health Organization. Global Status Report on Non-Communicable Disaeses. 2011.

3. Delima, Laurentia M, Hadi S. Prevalensi dan Faktor Determinan Penyakit Jantung di Indonesia. Buletin Penelitian Kesehatan 2009; 37(3):145-9.

4. Departemen Kesehatan RI. Riset Kesehatan Dasar (RISKESDAS). 2013

5. Lim SS, Theo V, Abraham DF, Goodarz D, Shibuya K, Adair-Rohani $\mathrm{H}$ et al. A Comparative Risk Assessment of Burden of Disease and Injury Attributable to 67 Risk 
Factors and Risk Factor Clusters in 21 Regions, 1990-2010: A Systematic Analysis for The Global Burden of Disease Study 2010. Elsevier 2012; 380(9859):2224-55

6. Bittner V. Perspectives on Dyslipidemia and Coronary Heart Disease in Women. Journal of American College of Cardiology 2005; 46(9):1632.

7. Perkumpulan Endokrinologi Indonesia (Perkeni). Petunjuk Praktis Penatalaksanaan Dislipidemia. 2004.

8. Varady KA, Peter JHJ. Combination Diet and Exercise Interventions for the Treatment of Dyslipidemia: an Efective Preliminary Strategy to Lower Cholesterol Levels. Journal of Nutrition 2005; 135 (8):1829-30.

9. Rachmandiar R. Perbedaan Pengaruh Jus Kacang Merah, Yoghurt Susu, dan Yoghurt Kacang Merah Terhadap Kadar Kolesterol Total dan Trigliserida Serum pada Tikus Dislipidemia. Artikel Karya Tulis Ilmiah Mahasiswa Program Studi Kedokteran Umum. FK. Undip Semarang; 2012.

10. Maruyama C, Araki R, Kawamura M, Kondo N, Kigawa M, Kawai Y, Takanami Y et al. Azuki Bean Juice Lowers Serum Trigliseride Concentration in Healthy Young Women. J Clin Biochem Nutr 2008; 43(1):19-24.

11. McPherson L. Effects of the Consumption of Fully Cooked Red Kidney Beans (Phaseolus Vulgaris) on the Growth Rate of Rats and the Morphology of the Gut Wall. J Sci Food Agric 1991; 57:611, 613-8.

12. Nakamura Y, Akiko K, Kimihiko Y, Yukari T, Susumu I, Yasuhide T. Content and Composition of Isoflavonoids in Mature or Immature Beans and Bean Sprouts Consumed in Japan. Journal of Health Science 2001; 47(4):399.

13. Reddy CK, M Suriya, Sundaramoorthy H. Physico-chemical and Functional Properties of Resistant Starch Prepared from Red Kidney Beans (Phaseolus vulgaris.L) Starch by Enzymatic Method. Elsevier 2013; 95(1): 220.

14. Andreson JW, Dee AD, Susan RB.Soluble Fiber Hypocholesterolemic Effects and Proposed Mechanisms. In: Kritchevsky D, Charles B, James WA, editors. Dietary Fiber Chemistry, Physiology, and Health Effects. New York: Plenum Press; 1990.p.350-6.

15. Kwang GL, Takayuki S, Gary RT, Lee SU, Kim JH, Park BS. Inhibitory Effects of PlantDerived Flavonoids and Phenolic Acids on Malonaldehyde Formation from Ethyl
Arachidonate. J Agric Food Chem 2003; 51(24):7203-4.

16. Borradaile NM, Linda EDD, Lisa JW, Jane YE, Murray WH. Soya Phytoestrogens, Genistein and Daidzein, Decrease Apolipoprotein B Secretion from HepG2 Cells Through Multiple Mechanisms. J Biochem 2002; 366:531-2.

17. Goktepe I, Vijay KJ, Mohamed A. Probiotics in Foods Safety and Human Health. USA: Taylor and Francis Group; 2006.p.21.

18. Le D, Alvin G, Vitool L, Michelle AW. Prevalence and Risk Factors of Hypercholesterolemia Among Thai Men and Women Receiving Health Examinations. J. Trop. Med. Public Health 2006; 37(5):1008.

19. Raymond JL, Sarah CC. Medical Nutrition Therapy for Cardiovascular Disease. In: Mahan LK, Escott-Stump S, Editors. Krause's Food and the Nutrition Care Process. 13rd ed. USA: Elsevier; 2012.p.743-57.

20. Nilawati S, Diah K, Mahendra B, Oie GD. Care yourself: Kolesterol. Jakarta: Penebar Plus; 2008.p.18;24.

21. Rahmawati AC, Siti Z, Setyaningrum R. Aktivitas Fisik dan Rasio Kolesterol (HDL) pada Penderita Penyakit Jantung Koroner di Poliklinik Jantung RSUD Dr Moewardi Surakarta. Jurnal Kedehatan 2009; 2(1):12.

22. Holli BB, Judith AB. Nutrition Counseling and Education Skill for Dietetics Professionals. 6th ed. Philadelphia: Wolter Kluwer, Lippincott Williams and Wilkins; 2013.p.1.

23. Ebbert JO, Michael DJ. Fat Depots, Free Fatty Acids, and Dyslipidemia. J Nutr 2013; 5(2):498.

24. Mi LE, Lee SS, Chung BY, Cho JY, Lee IC, Ahn SR et al. Pancreatic Lipase Inhibition by $C$-Glycosidic Flavones Isolated from Eremochloa ophiuroides. MDPI Journal 2010; 15(11):8252.

25. Hwang JT, Park IJ, Shin JI, Lee YK, Lee SK, Baik HW et al. Genistein, EGCG, and Capsaicin Inhibit Adipocyte Differentiation Process via Activating AMP-Activated Protein Kinase. Biochem Biophys Res Commum 2005; 338(2): 694-9.

26. Pyo HY, Tung CL, Young CL. Enrichment of bioactive isoflavones in soymilk fermented with b-glucosidase-producing lactic acid bacteria. Elsevier 2004; 38(5):551-2.

27. Winarsi H. Isoflavon: Berbagai Sumber, Sifat, dan Manfaatnya pada Penyakit Degeneratif. Yogyakarta: Gadjah Mada University Press; 2005.p.36, 41. 
28. Scottish Intercollegiate Guidelines Network. Risk Estimation and The Prevention of Cardiovascular Disease: A National Clinical Guideline. 2007.

29. Botham KM, Peter AM. Sintesis, Transpor, dan Ekskresi Kolesterol. Dalam: Murray RK, Darly KG, Victor WR, editor. Braham UP, alih bahasa. Biokimia Harper. 27 ed. Jakarta: EGC; 2009.p.220.

30. Guyton AC, Hall JE. Textbook of Medical Physiology. 11 st ed. USA: Elsevier; 2006.p.243. 